\title{
Uji Validitas dan Efikasi Crypto/Giardia Duo-Strip dalam Mendeteksi Cryptosporidium spp. di Desa Tulehu, Kabupaten Maluku Tengah, Provinsi Maluku
}

\author{
Rizqiani A. Kusumasari ${ }^{1}$ dan M. Syairaji ${ }^{2}$ \\ ${ }^{1}$ Departemen Parasitologi, Fakultas Kedokteran, Kesehatan Masyarakat dan Keperawatan, \\ Universitas Gadjah Mada \\ ${ }^{2}$ Departemen Layanan dan Informasi Kesehatan Sekolah Vokasi, \\ Universitas Gadjah Mada \\ msyairaji@ugm.ac.id²
}

\author{
Diajukan 13 April 2020 Diperbaiki 19 Agustus 2020 Diterima 25 Agustus 2020 \\ ABSTRAK
}

Latar Belakang: Cryptosporidium spp. adalah salah satu enteropatogen pada manusia dan umumnya ditemui terutama pada anak-anak di negara berkembang. Prevalensi Cryptosporidium spp. di Indonesia masih belum diketahui dan penelitian terkait juga masih sangat jarang. Saat ini, beberapa perusahaan telah mengembangkan tes diagnostik sederhana dan cepat untuk mendeteksi infeksi Cryptosporidium spp. tetapi informasi mengenai keakuratannya pada kondisi di Indonesia masih belum diketahui.

Tujuan: Mengetahui validitas alat Crypto/Giardia Duo-Strip dan prevalensi Cryptosporidium spp. pada salah satu wilayah pedesaan di timur Indonesia.

Metode: Penelitian ini menggunakan desain potong-lintang dan dilakukan tahun 2015. Sampel tinja dikumpulkan dari seluruh masyarakat di desa Hurnala, Maluku Tengah. Validitas (Sensitifitas, Spesifisitas) dan Efikasi (Nilai Prediktif Positif dan Negatif) dari Crypto/Giardia Duo-Strip dinilai menggunakan Modified acid-fast staining sebagai standar referensi.

Hasil: Dari 731 sampel tinja, terdapat 261 sampel positif Cryptosporidium spp. menggunakan Modified acid-fast staining dan 204 sampel positif menggunakan Crypto/Giardia Duo-Strip. Sensitivitas, Spesifisitas, PPV, dan NPV Crypto/Giardia Duo-Strip masing-masing sebesar 38.78\%, 78.99\%, 35.77\%, 69.64\% dengan Likelihood Ratio+ (LR+): 1.77 and (LR-): 0.79.

Kesimpulan: Prevalensi infeksi Cryptosporidium spp. di desa Hurnala, Maluku Tengah cukup tinggi yaitu 36\% (261/731). Kemampuan alat Crypto/Giardia Duo-Strip masih relatif rendah untuk mendeteksi Cryptosporidium spp. di wilayah Indonesia.

Kata kunci: cryptosproridium; validitas; crypto/giardia duo-strip; prevalensi

\section{ABSTRACT}

Background: Cryptosporidium spp. is one of the common human enteropathogens found especially in children in developing countries. Prevalence of Cryptosporidium spp. in Indonesia is still unknown and related research is also very rare. Nowadays, several companies have developed simple and quick diagnostic tests to detect Cryptosporidium infections, but information about its accuracy is unknown.

Objective: To determine the prevalence of Cryptosporidium spp. and the validity of Crypto/Giardia Duo-Strip in eastern Indonesia rural area.

Methods: This research has a cross-sectional study design and was conducted in 2015. Fecal samples were collected from all population in Hurnala village, Central Maluku. Validity (Sensitivity, Specificity) and Efficacy (Positive and Negative Predictive Value) of Crypto/Giardia Duo-Strip were assessed using Modified acid-fast staining as a standard.

Results: From 731 stool sample, 261 positives of Cryptosporidium spp. based on Modified acid-fast staining and 204 positives using Crypto/Giardia Duo-Strip. Sensitivity, specificity, PPV, and NPV for Crypto/Giardia DuoStrip were $38.78 \%, 78.99 \%, 35.77 \%, 69.64 \%$ with Likelihood Ratio (LR+): 1.77 and (LR-): 0.79 .

Conclusion: Prevalence of Cryptosporidium spp. in Hurnala village, Maluku Tengah is quite high which is 36\% (261/731). Crypto/Giardia Duo-Strip tools did not show good performance for detecting Cryptosporidium in Indonesian condition.

Keywords: cryptosporidium; validity; crypto/giardia duo-strip; prevalence 
PENDAHULUAN

Cryptosporidium spp. adalah salah satu enteropatogen yang paling umum ditemui terutama pada usia anak di negara-negara berkembang. Enteropatogen ini berhubungan erat dengan kejadian diare berkepanjangan dan penyebab morbiditas dan mortalitas pada anak. Jenis diare yang berkaitan dengan Cryptosporidium ini adalah diare berkepanjangan dengan durasi 7-14 hari dan diare persisten dengan durasi lebih dari 14 hari (Checkley et al., 2015). Penyebaran infeksi protozoa penyebab diare ini dapat berkelanjutan karena didukung faktor transmisi rute fecal-oral dan banyaknya penderita asimtomatik (Becker et al., 2017).

Prevalensi Cryptosporidium spp. di Indonesia masih belum diketahui dan penelitian terkait juga masih sangat jarang. Wijayanti (2017) melaporkan bahwa kejadian Cryptosporidiosis di Indonesia merupakan urutan ketiga angka kesakitan dan kematian anak saat ini yang berkaitan dengan diare (Wijayanti, 2017). Kejadian Cryptosporidiosis cukup penting untuk dideteksi awal pada pasien yang mengidap HIV/AIDS dan tuberkulosis karena sifat parasit ini oportunistik terutama pada individu imunokompromi (Hunter \& Nichols, 2002). Data menunjukkan bahwa spesies parasit ini menyebabkan kasus diare antara $4-11 \%$ di Indonesia (Widoyono, 2011).

Metode standar yang digunakan secara umum dalam mendeteksi adanya infeksi Cryptosporidiosis adalah metode Acid-fast staining dengan melihat adanya warna merah pada sampel positif yang dilihat dibawah mikroskop (DPDx, 2019). Saat ini, beberapa perusahaan telah mengembangkan tes diagnostik sederhana dan cepat untuk memudahkan dalam mendeteksi adanya Cryptosporidium langsung dari sampel feses. Tes cepat dan sederhana ini sangat relevan untuk digunakan, terutama di daerah endemik dengan fasilitas terbatas seperti mikroskop dan centrifuge yang dibutuhkan pada pemeriksaan standar (Boelaert, 2016). Hanya saja, informasi mengenai keakuratannya penggunaan tes diagnostik cepat (Rapid Diagnostic Test/ $R D T$ ) pada situasi Indonesia masih belum diketahui secara pasti (Wijayanti, 2017).

Tujuan penelitian ini untuk mengetahui validitas dari alat diagnostik Cryptosporidium spp. menggunakan Crypto/ Giardia Duo-Strip yang merupakan salah satu jenis tes diagnostik cepat (Rapid Diagnostic Test/RDT). Manfaat penelitian yang dilakukan yaitu mendapatkan data mengenai validitas dan efikasi dari penggunaan alat diagostik cepat berupa Crypto/Giardia Duo-Strip di wilayah pedesaan sekaligus mengetahui prevalensi kejadian penyakit Criptosporidiosis di wilayah tersebut.

\section{METODE}

Penelitian ini merupakan bagian dari bagian studi multisenter yang dilakukan di empat negara mengenai gangguan pencernaan persisten dalam skema proyek NIDIAG (www.nidiag.org). Penelitian ini dilakukan menggunakan desain studi potong lintang yang dilakukan pada tahun 2015. Kriteria inklusinya adalah seluruh populasi masyarakat yang tinggal di desa Hurnala, Kabupaten Maluku Tengah lebih dari 1 tahun dan berusia lebih dari 1 tahun. Populasi masyarakat yang masuk kriteria inklusi kemudian diwawancarai dan diambil sampel tinjanya. Dari 918 orang populasi yang masuk kedalam kriteria inklusi, 907 orang memberikan consent/ persetujuannya dan sebanyak 731 partisipan bersedia mengumpulkan sampel tinja.

Karakteristik partisipan yang didata berupa data umur, jenis kelamin, pekerjaan dan pendidikan. Adapun untuk sampel tinjanya dilakukan pemeriksaan dengan menggunakan Crypto/Giardia DuoStrip yang dikonfirmasi dengan metode pewarnaan Modified Acid-fast (Ziehl- 
Neelsen).

\section{Crypto/Giardia Duo-Strip}

Alat tes diagnostik secara cepat (Rapid Diagnostic Test/RDT) yang digunakan adalah Crypto/Giardia Duo-Strip (article no. C-1018) produksi Coris BioConcept, dari Gembloux, Belgium. Cara penggunaannya cukup mudah dan dapat mendeteksi Cryptosporidium dan Giardia intestinalis (CorisBio, 2012).

Prosedurnya seperti pada gambar 1 , yaitu diawali dengan menambahkan 0,5 $\mathrm{ml}$ atau 15 tetes larutan dilution buffer ke dalam tabung reaksi. Lalu diambil sampel tinja menggunakan stik sampel dan masukkan ke dalam tabung reaksi. Rasio pelarutan harus berkisar $4 \% \mathrm{w} / \mathrm{v}$. Untuk sampel cair, sampel diambil 2 kali dengan stik sampel sekitar $10 \mu \mathrm{l}$; sedangkan untuk tinja padat hanya ambil 1 kali dengan stik sampel. Setelah selesai, stik sampel bekas dibuang ke dalam tempat sampah.

Kemudian, tabung reaksi tersebut divortex agar homogen hingga seluruh sampel tinja tersuspensi. Crypto/Giardia Duo-Strip dimasukkan ke dalam tabung dan direndam sesuai dengan petunjuk tanda panah merah yang terdapat pada strip. Lalu ditunggu hingga bereaksi dan hasilnya dibaca setelah 15 menit. Hasil positif ditandai dengan adanya garis kontrol dan garis tes tampak merah bersamaan dan hasil negatif ditandai dengan garis kontrol tampak merah tetapi garis tes tidak merah dalam waktu maksimal 15 menit. Hasil dianggap tidak valid jika tidak tampak garis kontrol (CorisBio, 2012).

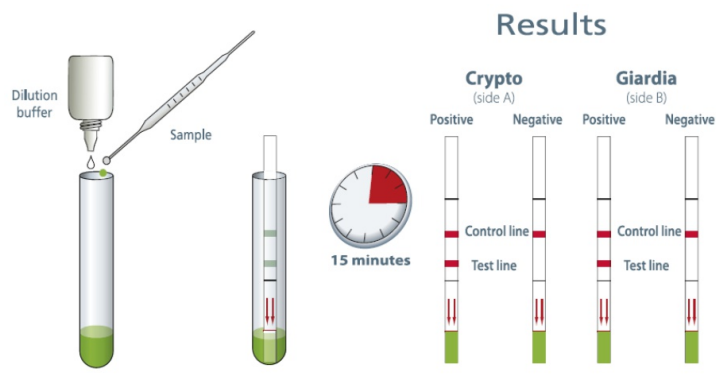

Gambar 1. Prosedur Pemeriksaan dengan Crypto/Giardia Duo-Strip
Pewarnaan Modified Acid-fast (ZiehlNeelsen)

Metode pewarnaan ini mampu mendeteksi protozoa usus yang patogen yaitu Coccidian pada sampel tinja manusia. Salah satu jenis Coccidian penting yang dapat menyebabkan gangguan saluran pencernaan menetap adalah Cryptosporidium spp. Patogen yang bersifat asam seperti Cryptosporidium spp. akan terwarnai kemerahan-merah muda (reddish-pink) dan mudah dibedakan dengan latar belakangnya.

Prosedurnya adalah menempatkan slide pada rak pewarnaan dan menggenanginya dengan Carbolfuchsin (ZN A) selama 4 menit tanpa dipanaskan lalu cuci menggunakan air mengalir. Selanjutnya, dekolorisasi dengan Decolorizer (ZB B) selama 3-5 detik dan dicuci dengan air mengalir. Slide tersebut kemudian digenangi lagi menggunakan Metilen Blue ( $\mathrm{ZN}$ C) selama 30 detik dilanjutkan dicuci dengan air mengalir dan dikeringkan. Setelahnya, slide siap diperiksa di bawah mikroskop secara hatihati dengan pembesaran 400x dan 1000x (Becker et al., 2013). Validitas (Sensitivitas, Spesifisitas) dan Efikasi (Nilai Prediktif Positif atau Positive Predictive Value/PPV dan Nilai Prediktif Negatif atau Negative Predictive Value/NPV) dari Crypto/Giardia Duo-Strip dinilai menggunakan Modified acid-fast staining (Ziehl-Neelsen) sebagai standar referensi.

\section{HASIL DAN PEMBAHASAN}

Penelitian ini dilakukan di populasi wilayah desa Hurnala, Kabupaten Maluku Tengah dengan populasi sampel dari seluruh warga yang memiliki umur diatas 1 tahun dan bersedia menjadi partisipan dalam penelitian. Partisipan yang bersedia ikut diambil beberapa data karakteristik diantaranya umur, jenis kelamin, pekerjaan dan pendidikan. Hasilnya terlihat pada tabel 1 di bawah ini. 
Uji Validitas dan Efikasi Crypto/Giardia Duo-Strip dalam Mendeteksi...

\begin{tabular}{lll}
\hline \multicolumn{3}{l}{ Tabel 1. Karakteristik Populasi Masyarakat } \\
Desa Hurnala, Kabupaten Maluku Tengah \\
(n=731)
\end{tabular}

*rerata \pm standar deviasi

TD: Tidak Diketahui

Tabel 1 menunjukkan bahwa sebagian besar partisipan adalah perempuan $(60 \%)$ dengan rata-rata umur 22 tahun. Pada aspek pekerjaan dan pendidikan sebagian besar partisipan tidak bekerja dan pelajar (masing-masing sebesar 38\%) dengan riwayat pendidikan terbanyak yaitu tidak pernah bersekolah (28\%). Berdasarkan karakteristik ini terlihat bahwa sebagian besar responden memiliki tingkat pendidikan yang rendah. Penduduk yang tidak bersekolah mendominasi sebanyak $28,18 \%$, diikuti oleh penduduk yang lulus SMA sebesar $21,75 \%$ dan penduduk yang lulus SD yaitu $18,88 \%$. Penduduk yang memiliki tingkat pendidikan hingga Perguruan Tinggi hanya 4,48\% dari populasi yang diamati. Hasil ini sejalan dengan karakteristik penyakit infeksi ini yang banyak terjadi di negara dengan tingkat pendidikan dan ekonomi rendah.

Prevalensi protozoa ini cukup bervariasi mulai dari $1 \%$ pada negara maju hingga sekitar $5-10 \%$ pada negara berkembang (Checkley et al., 2015). Negara-negara di Asia yang termasuk negara berkembang diketahui memiliki beban penyakit Criptosporidiosis pada populasi usia anak, didukung oleh hasil penelitian di Pakistan dan Iran (Aghamolaie et al., 2016; Khan et al., 2019; Tombang et al., 2019). Selain itu, menurut penelitian Shrivastava et al., (2017) menyimpulkan bahwa Cryptosporidium spp. turut menyumbang hampir $20 \%$ penyebab kasus diare pada anak-anak di negara-negara berkembang (Shrivastava et al., 2017).

Penyebabnya, karena penyakit infeksi protozoa ini memiliki hubungan yang erat dengan tingkat pendidikan dan pengetahuan mengenai bagaimana berperilaku hidup yang baik, bersih dan sehat dari tingkat keluarga. Diketahui juga bahwa kontaminasi dari penyakit ini banyak terdapat pada sumber air yang digunakan masyarakat ataupun bahan makanan yang tidak dipersiapkan dengan baik dan bersih (Bouzid et al., 2018; Wijayanti, 2017). Transmisi dari penyakit ini memang sedikit kompleks, tetapi berhubungan erat dengan lingkungan sanitasi yang buruk dengan kebiasaan higienitas yang rendah pula (Opoku et al., 2018).

Tabel 2. Hasil pemeriksaan sampel tinja untuk mendeteksi Cryptosporidium spp.

\begin{tabular}{cccc}
\hline \multirow{2}{*}{$\begin{array}{c}\text { Crypto/Giardia } \\
\text { Duo-Strip }\end{array}$} & \multicolumn{2}{c}{$\begin{array}{c}\text { Pewarnaan } \\
\text { Modified Acid- } \\
\text { Fast }\end{array}$} & Total \\
\cline { 2 - 3 } & Positif & Negatif & \\
\hline Positif & 101 & 103 & 204 \\
Negatif & 160 & 367 & 527 \\
Total & 261 & 470 & 731 \\
\hline
\end{tabular}

Dari 731 tinja yang dikumpulkan dan diperiksa, terdapat 261 sampel positif berdasarkan Modified acid-fast staining dan 204 sampel positif berdasarkan Crypto/ Giardia Duo-Strip. Hasil pemeriksaan berupa Sensitivitas dan Spesifisitas, diikuti Nilai Prediktif Positif atau Positive Predictive Value/PPV dan Nilai Prediktif 
Uji Validitas dan Efikasi Crypto/Giardia Duo-Strip dalam Mendeteksi...

Negatif atau Negative Predictive Value (NPV) Crypto/Giardia Duo-Strip masingmasing sebesar 38,78\%, 78,99\%, 35,77\%, 69,64\% dengan Likelihood Ratio+ (LR+): 1,77 and (LR-): 0,79.

Berdasarkan hasil ini, diketahui bahwa nilai sensitivitas dan PPV dari Crypto/Giardia Duo-Strip masih cukup rendah. Crypto/Giardia Duo-Strip hanya dapat mendeteksi 39\% dari prevalensi Cryptosporidium spp. dan hanya $36 \%$ yang positif Crypto/Giardia Duo-Strip yang juga menunjukkan hasil positif berdasarkan metode standar referensi (Modified acid-fast staining). Hasil perhitungan Likelihood Ratio juga menunjukkan bahwa alat ini memiliki nilai prediksi yang rendah untuk kasus infeksi Cryptosporidium spp. Probabilitas hasil positif pada Crypto/ Giardia Duo-Strip tidak cukup kuat untuk memprediksi hasil positif berdasar pada standar referensinya (real positive).

Hasil ini berbeda dengan penelitian di Malawi dan Kenya dengan sampel anak-anak dengan malnutrisi dan diare akut parah. Hasilnya, menunjukkan bahwa hasil dengan RDT sejalan dengan hasil pemeriksaan menggunakan PCR, dimana hasil di Malawi lebih rendah daripada hasil di Kenya baik menggunakan RDT maupun PCR. Validitas berupa sensitivitas berkisar antara $42,9 \%$ hingga $76,9 \%$ dan spesifisitasnya berkisar antara 88,4\% hingga $100 \%$ untuk Cryptosporidiosis (Bitilinyu-Bangoh et al., 2019).

Studi dari Perancis menunjukkan bahwa RDT merupakan alat diagnosis yang dapat diandalkan sebagai alternatif dari metode pewarnaan Ziehl-Neelsen. Sensitivitas atau spesifisitas untuk mendeteksi Giardia intestinalis dan Cryptosporidium masing-masing sebesar $89,2 \% / 99,3 \%$ dan $86,7 \% / 100 \%$ (Goudal et al., 2019). Hasil dari penelitian di Belgia menggunakan alat strip RDT yang sama juga menunjukkan hasil sensitivitas sebesar $58,3 \%$ dan spesifisitas sebesar $100 \%$ (Van den Bossche et al., 2015) sedangkan pada penelitian di Inggris, hasil pengukuran spesifisitas dari Immunochromatographic lateral flow assay (ICLF) dengan sensitivitasnya mencapai $84.9 \%$ dan spesifisitasnya $100 \%$ (Chalmers et al., 2011).

Beberapa penelitian melakukan pemeriksaan menggunakan RDT sebagai uji cepat yang mudah dilakukan dengan fasilitas terbatas. Pemeriksaan ini juga dianggap lebih sensitif dalam mendeteksi protozoa usus jika dibandingkan pemeriksaan mikroskopis yang sudah ada sebelumnya. Namun, akurasi dari diagnosis ini juga dilaporkan berbeda dari satu penelitian dengan penelitian lain serta dapat menghasilkan hasil yang berbeda jika diterapkan pada sampel tinja pada individu yang tanpa gejala (Becker et al., 2017). Dalam sebuah ulasan terbaru, disimpulkan bahwa RDT harus digunakan untuk melengkapi pemeriksaan mikroskopis agar dapat meningkatkan akurasi diagnosis menggunakan tinja dari infeksi protozoa usus manusia (Goñi et al., 2012; Soares \& Tasca, 2016).

\section{PENUTUP}

Dari hasil penelitian dan analisis data, menunjukkan prevalensi infeksi Cryptosporidium spp. yang tinggi di Desa Hurnala, Kabupaten Maluku Tengah, Provinsi Maluku yaitu sebesar 36\% (261/731) dengan sensitivitas sebesar 38,78\% dan spesifisitas sebesar 78,99\%. Hasil sensitivitas Crypto/Giardia Duo-Strip masih relatif rendah untuk wilayah Indonesia jika dibandingkan dengan penelitian dengan kasus yang serupa di negara lain.

\section{UCAPAN TERIMA KASIH}

Penulis mengucapkan terima kasih atas arahan dari Fransiska Meyanti, Elsa Herdiana Murhandarwati, Katja Polman, Söeren L. Becker dan Yodi Mahendradhata selama melaksanakan penelitian. Tim penulis juga ingin memberikan ucapan terima kasih kepada Irene Meity Rahakbauw, Ratih Restiani, dan Henry Surendra atas bantuannya dalam koordinasi penelitian dan pengambilan data. 
DAFTAR PUSTAKA

Aghamolaie, S., Rostami, A., Fallahi, S., Tahvildar Biderouni, F., Haghighi, A., \& Salehi, N. (2016). Evaluation of modified Ziehl-Neelsen, direct fluorescent-antibody and PCR assay for detection of Cryptosporidium spp. in children faecal specimens. Journal of Parasitic Diseases: Official Organ of the Indian Society for Parasitology, 40(3), 958-963. https://doi.org/10.1007/ s12639-014-0614-4

Becker, S. L., Müller, I., Mertens, P., Herrmann, M., Zondie, L., Beyleveld, L., Gerber, M., du Randt, R., Pühse, U., Walter, C., \& Utzinger, J. (2017). PCR-based verification of positive rapid diagnostic tests for intestinal protozoa infections with variable test band intensity. Acta Tropica, 174, 4955 .

https://doi.org/10.1016/ j.actatropica.2017.06.012

Becker, S. L., Vogt, J., Knopp, S., Panning, M., Warhurst, D. C., Polman, K., Marti, H., von Müller, L., Yansouni, C. P., Jacobs, J., Bottieau, E., Sacko, M., Rijal, S., Meyanti, F., Miles, M. A., Boelaert, M., Lutumba, P., van Lieshout, L., N'Goran, E. K., ... Utzinger, J. (2013). Persistent digestive disorders in the tropics: causative infectious pathogens and reference diagnostic tests. BMC Infectious Diseases, 13, 37. https://doi.org/ 10.1186/1471-2334-13-37

Bitilinyu-Bangoh, J., Voskuijl, W., Thitiri, J., Menting, S., Verhaar, N., Mwalekwa, L., de Jong, D. B., van Loenen, M., Mens, P. F., Berkley, J. A., Bandsma, R. H. J., \& Schallig, H. D. F. H. (2019). Performance of three rapid diagnostic tests for the detection of Cryptosporidium spp. and Giardia duodenalis in children with severe acute malnutrition and diarrhoea. Infectious Diseases of Poverty, 8(1), 96. https://doi.org/10.1186/s40249-0190609-6

Boelaert, M. (2016). Clinical Research on
Neglected Tropical Diseases:

Challenges and Solutions. PLOS Neglected Tropical Diseases, 10(11), e0004853. https://doi.org/10.1371/ journal.pntd.0004853

Bouzid, M., Kintz, E., \& Hunter, P. R. (2018). Risk factors for Cryptosporidium infection in low and middle income countries: A systematic review and meta-analysis. PLOS Neglected Tropical Diseases, 12(6), e0006553. https://doi.org/ 10.1371/journal.pntd.0006553

Chalmers, R. M., Campbell, B. M., Crouch, N., Charlett, A., \& Davies, A. P. (2011). Comparison of diagnostic sensitivity and specificity of seven Cryptosporidium assays used in the UK. Journal of Medical Microbiology, 60(11), 1598-1604. https://doi.org/ 10.1099/jmm.0.034181-0

Checkley, W., White, A. C., Jaganath, D., Arrowood, M. J., Chalmers, R. M., Chen, X.-M., Fayer, R., Griffiths, J. K., Guerrant, R. L., Hedstrom, L., Huston, C. D., Kotloff, K. L., Kang, G., Mead, J. R., Miller, M., Petri, W. A., Priest, J. W., Roos, D. S., Striepen, B., ... Houpt, E. R. (2015). A review of the global burden, novel diagnostics, therapeutics, and vaccine targets for cryptosporidium. The Lancet. Infectious Diseases, 15(1), 85-94. https://doi.org/ 10.1016/S1473-3099(14)70772-8

CorisBio. (2012). Coris Bio Crypto/Giardia Duo-Strip: Rapid Diagnostic Test for in vitro Detection of Cryptosporidium and Giardia in stool specimens. CorisBio.Com. https:// www.corisbio.com/pdf/Products/ Coris-Crypto-Giardia-Duo-StripDiagnostic.pdf

DPDx. (2019). Cryptosporidiosis (Cryptosporidium spp.). CDC (Center for Disease Control and Prevention). https://www.cdc.gov/dpdx/ cryptosporidiosis/index.html

Goñi, P., Martín, B., Villacampa, M., García, A., Seral, C., Castillo, F. J., \& 
Clavel, A. (2012). Evaluation of an immunochromatographic dip strip test for simultaneous detection of Cryptosporidium spp, Giardia duodenalis, and Entamoeba histolytica antigens in human faecal samples. European Journal of Clinical Microbiology $\mathcal{E}$ Infectious Diseases, 31(8), 2077-2082. https://doi.org/ 10.1007/s10096-012-1544-7

Goudal, A., Laude, A., Valot, S., Desoubeaux, G., Argy, N., Nourrisson, C., Pomares, C., Machouart, M., Le Govic, Y., Dalle, F., Botterel, F., Bourgeois, N., Cateau, E., Leterrier, M., Lavergne, R.-A., Beser, J., Le Pape, P., \& Morio, F. (2019). Rapid diagnostic tests relying on antigen detection from stool as an efficient point of care testing strategy for giardiasis and cryptosporidiosis? Evaluation of a new immunochromatographic duplex assay. Diagnostic Microbiology and Infectious Disease, 93(1), 33-36. https:// doi.org/10.1016/j.diagmicrobio.

2018.07.012

Hunter, P. R., \& Nichols, G. (2002). Epidemiology and Clinical Features of Cryptosporidium Infection in Immunocompromised Patients. Clinical Microbiology Reviews, 15(1), 145-154. https://doi.org/10.1128/CMR. 15.1.145-154.2002

Khan, A., Shams, S., Khan, S., Khan, M. I., Khan, S., \& Ali, A. (2019). Evaluation of prevalence and risk factors associated with Cryptosporidium infection in rural population of district Buner, Pakistan. PLOS ONE, 14(1), e0209188. https://doi.org/ 10.1371/journal.pone.0209188

Opoku, Y. K., Boampong, J. N., Ayi, I., Kwakye-Nuako, G., Obiri-Yeboah, D., Koranteng, H., Ghartey-Kwansah, G., \& Asare, K. K. (2018). SocioBehavioral Risk Factors Associated with Cryptosporidiosis in HIV/AIDS Patients Visiting the HIV Referral
Clinic at Cape Coast Teaching Hospital, Ghana. The Open AIDS Journal, 12(1), 106-116. https://doi.org/ 10.2174/1874613601812010106

Shrivastava, A. K., Kumar, S., Smith, W. A., \& Sahu, P. S. (2017). Revisiting the global problem of cryptosporidiosis and recommendations. Tropical Parasitology, 7(1), 8-17. https://doi.org/ 10.4103/2229-5070.202290

Soares, R., \& Tasca, T. (2016). Giardiasis: an update review on sensitivity and specificity of methods for laboratorial diagnosis. Journal of Microbiological Methods, 129, 98-102. https://doi.org/ 10.1016/j.mimet.2016.08.017

Tombang, A. N., Ambe, N. F., Bobga, T. P., Nkfusai, C. N., Collins, N. M., Ngwa, S. B., Diengou, N. H., \& Cumber, S. N. (2019). Prevalence and risk factors associated with cryptosporidiosis among children within the ages $0-5$ years attending the Limbe regional hospital, southwest region, Cameroon. BMC Public Health, 19(1), 1144. https://doi.org/10.1186/s12889019-7484-8

Van den Bossche, D., Cnops, L., Verschueren, J., \& Van Esbroeck, M. (2015). Comparison of four rapid diagnostic tests, ELISA, microscopy and PCR for the detection of Giardia lamblia, Cryptosporidium spp. and Entamoeba histolytica in feces. Journal of Microbiological Methods, 110, 78-84. https://doi.org/10.1016/j.mimet. 2015.01.016

Widoyono. (2011). Penyakit Tropis Epidemiologi, Penularan, Pencegahan $\mathcal{E}$ Pemberantasannya. Edisi kedua (R. Astikawati (ed.); Ed.2). Erlangga.

Wijayanti, T. (2017). Kriptosporidiosis Di Indonesia. Jurnal Litbang Pengendalian Penyakit Bersumber Binatang Banjarnegara, 13(1), 73-82. https:// www.neliti.com/id/publications/69108/ kriptosporidiosis-di-indonesia\#cite 